
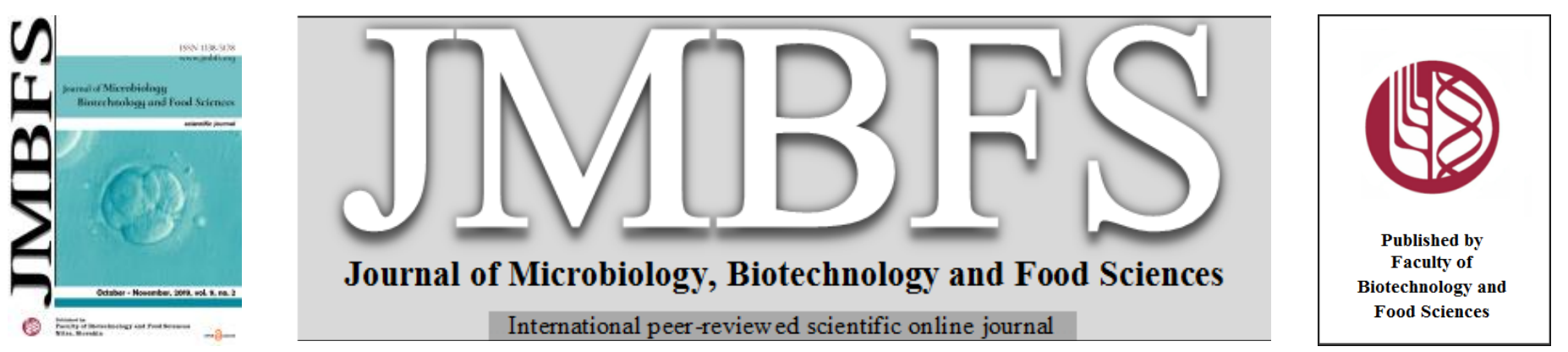

\title{
PHYSICOCHEMICAL, FUNCTIONAL AND SENSORY PROPERTIES OF ACHA-TAMBA BASED OGI ENRICHED WITH HYDROLYSED SOY PEPTIDES
}

\author{
Ogori A. $F^{1,}{ }^{*}$, Uzor O. $A^{1,2}$, Lukas Hleba ${ }^{3}$, Miroslava Císarová ${ }^{4}$, Alexey Glinushkin ${ }^{5,6,7}$, Alexey Laishevtcev ${ }^{8,9}$, Anna Derkanosova ${ }^{10}$, \\ Pigorev Igor ${ }^{11}$, Sergey Plygun ${ }^{9,12,13}$, Mohammad Ali Shariati ${ }^{9, *}$
}

\begin{abstract}
$\operatorname{Address(es):~}$
${ }^{1}$ Department of Food Science and Technology, Federal University of Agriculture, Makurdi, Benue State, Nigeria.

${ }^{6}$ Professor of the Russian Academy of Sciences, Moscow, Russia.

${ }^{7}$ Professor, Orenburg State Agrarian University, Orenburg, Russia. Kovalenko of the Russian Academy of Sciences, Moscow, 109428, Russia.

Voronezh, 394036, Russia.

${ }^{11}$ Professor, Vice Rector on Science, Kursk State Agricultural Academy, Kursk, 305021, Russia

${ }^{12}$ European Society of Clinical Microbiology and Infectious Diseases, Basel, 4051, Switzerland.

${ }^{13}$ All Russian Research Institute of Phytopathology, Moscow Region, 143050, Russia.
\end{abstract}

${ }^{2}$ Department of Home Science, Faculty of Agriculture, Federal University, Gashua, P.M.B.1005 Gashua, Yobe State, Nigeria.

${ }^{3}$ Department of Microbiology, Faculty of Biotechnology and Food Sciences, Slovak University of Agriculture in Nitra, Nitra, Slovak Republic.

${ }^{4}$ University of SS. Cyril and Methodius, Department of Biology, Faculty of Natural Sciences, Nám. J. Herdu 2, SK-91701 Trnava, Slovak Republic.

${ }^{5}$ Doctor of Agricultural Sciences, Head of Department of Resistance Studies, All Russian Research Institute of Phytopathology, Moscow Region, Russia.

${ }^{8}$ Senior Researcher, Federal Research Center - All-Russian Scientific Research Institute of Experimental Veterinary Medicine named after K.I. Skryabin and Y.R

${ }^{9}$ Laboratory of Biological Control and Antimicrobial Resistance, Orel State University named after I.S. Turgenev, Orel City, 302026, Russia.

${ }^{10}$ Candidate of Technical Sciences, Associate Professor, Department of service and restaurant business, Voronezh state university of engineering technologies,

*Corresponding author: ogorifaraday@gmail.com; shariatymohammadali@gmail.com

doi: $10.15414 / j m b f s .2020 .9 .4 .823-830$

ARTICLE INFO

Received 19. 7. 2019

Revised 12.9. 2019

Accepted 23. 10. 2019

Published 3. 2. 2020

Regular article

open $\partial_{\text {ACCESS }}$

\section{ABSTRACT}

The Physicochemical, Functional and Sensory Properties of Acha-tamba based Ogi Enriched with hydrolyzed Soy Peptides were investigated. The proximate value moisture content increased with percentage inclusion of acha tamba and peptides additions (10.1$11.5) \%$ Similar trend were observed in protein values (2.15-8.02) \%, Ash (3.05-3.34) \%, crude, fiber (7.05-10.6) \% and carbohydrate content 65.9-69.2) \% which had down tail trends on acha ,tamba and peptides percentage inclusions. Water absorption capacity (1.071.24) $\mathrm{g} / \mathrm{ml}$ oil absorption capacity (1.10-1.91) $\mathrm{g} / \mathrm{ml}$ and swelling index (3.06-3.50) $\mathrm{g} / \mathrm{ml}$ revealed increased content with material inclusions. The chemical properties of PH (4.27-4.6), Titratable acidity (0.88-0.97) and Total soluble solids were favored with material percentage inclusion. The sensory results revealed that sample Band sample C with moderate percentage inclusion of $10 \%$ and $20 \%$ acha, tamba and soypeptides were more acceptable by panelists.

Keywords: Physiochemical, Functional, Acha, Tamba, SoyPeptides, Flour, Blends

\section{INTRODUCTION}

Ogi is a fermented cereal pudding traditionally prepared from maize, sorghum or millet (Inyang and Idoko, 2006). In many parts of Nigeria and Africa gelatinized ogi is called pap and predominantly used as a traditional infant weaning food as well as breakfast meal for many adults in Africa (Inyang and Idoko, 2006: Ogodo et al., 2015). It is also one of the recommended meals that growing children graduate from breast milk. Ogi (Pap) also known as mieliepap (Afrikaans for maize porridge) in South Africa or Sadza in Shona or Isitshwala in Isindebele language in Zimbabwe or phaletšhe in Botswana is a traditional porridge/polenta made from mielie-meal (ground maize. In Nigeria, it is called akamu amongst the Igbo, Ogi or Akamu amongst the Yorubas and Koko amongst the Hausas with a consistency similar to American pudding.

During Ogi processing, nutrients including protein and minerals are lost from the grains thereby reducing the nutritional quality adversely. To improve the nutritional value of ogi, researchers have fortified it with either plant protein (melon, okro, cowpea, and soybean) or animal protein sources (egg and milk). For this study, Acha-tamba ogi will be enriched with soy peptides to improve the depleted nutrients (Omole et al., 2017; Ajanaku et al., 2017).

In this research, the researcher is interested in using soybean peptides to determine if on application, can help improve the lost nutrients in ogi.

Acha (Fonio) is the term for two cultivated grains in the Digitaria genus which are notable crops in parts of West Africa. The grains are very small. The crops have $\mathrm{C} 4$ metabolisms and are medium in height. The crop has species like white fonio, D. exilis, also called "hungry rice," which is the most important of a diverse group of wild and domesticated.

It has potential to improve nutrition, boost food security, foster rural development, and support sustainable use of the land. Fonio has continued to be important locally because it is both nutritious and one of the world's fastestgrowing cereals, reaching maturity in as little as six to eight weeks. Another species is black fonio (Digitaria iburua) which is a similar crop grown in Nigeria, Niger, Mali, Guinea, Togo, and Benin, Ghana (Adoukonou-Sagbadja et. al., 2007). Fonio grains are also considered as the best tasting and nutritious of all grains with about $7 \%$ crude protein that is high in leucine $(9.8 \%)$, methionine $(5.6 \%)$ and valine $(5.8 \%)$. The grains are also reported to have high brewing and malting potentials (Vietmeyer et al., 2011).

Tamba (Eleusine coracana) or finger millet, is an annual herbaceous plant widely grown as a cereal crop in the arid and semiarid areas in Africa and Asia. It is a tetraploid and self-pollinating species probably evolved from its wild relative Eleusine africana.Tamba is native to the Ethiopian and Ugandan highlands. Interesting crop characteristics of finger millet are the ability to withstand cultivation at altitudes over 2000 meters above sea level, its favourable micronutrient contents (high iron and methionine content in particular), its high drought tolerance and the very long storage time of the grains (Krishna, 2013).

Tamba is especially valuable as it contains the amino acid methionine, which is lacking in the diets of hundreds of millions of the poor who live on starchy staples such as cassava, plantain, polished rice, or maize meal. Tamba can be ground and cooked into cakes, puddings or porridge. The grain is made into a fermented drink (or beer) in Nepal and in many parts of Africa (Nigeria). The 
straw from tamba is used as animal fodder. It is also used for a flavoured drink in festivals.

Soybean (Glycine max) is economically the most important bean in the world, and a potential source of bioactive peptides. It produces also the essential amino acid found in animal protein. To ensure a nutrient balancing in ogi produced, soybean peptide is used. Soybean Peptides is made from non-GMO isolated soy protein. It is a super amino acid that is used as a nutrient balancing supplement. Soybean Peptides is a white granule powder that is similar to sugar. This product can be used in beverage and dairy products (Onyeka and Dibia, 2002).. Ogi according to Onyeka and Dibia, (2002) has low nutritional attributes because of the loss of nutrients including protein and minerals that are present in the grains thereby affecting its nutritional quality adversely

By incorporating ogi with non-cereal plant materials such as soybean can improve its nutritional value. Energy-protein mal-nutrition has been one of the major health challenges experienced in many African societies including Nigeria (Ubesie $\boldsymbol{e t} \boldsymbol{a l}$., 2012). Ogi is highly consumed in many African societies as breakfast meal and children's substituted meal for breast milk and will be a laudable vehicle for nutrient enrichment for the reduction of malnutrition incidences. Acha and tamba flours are good ogi making alternative raw materials away from the traditional cereals (maize, sorghum and millet) and when enriched with soy peptides, will play a significant role in improving cereal based diets of Nigerians.Ogi made from fermented cereals, is known from research to be deficient in some nutrients such as protein, vitamins and minerals. Moreover, cereals have also been reported to be limited in essential amino acids (lysine and tryptophan with super essentiality), while oil seeds and legumes meals are rich in these essential amino acids. Thus, combining acha and tamba flours with addition of soy peptides will improve the nutritional value of the resulting flour blends for ogi production.

\section{MATERIALS AND METHODS}

\section{Raw Material}

Acha and tamba grains used in this research will be purchased from North Bank market in Makurdi, Benue State while soybean peptide will be obtained in a food and chemical shop at Benue Crescent Makurdi town, Benue-State. Both Acha and Tamba obtained will be processed into Ogi in the Food Science and technology laboratory, Federal University of Agriculture, Makurdi (UAM) which is also the place where most of the laboratory work on this research will be carried out.
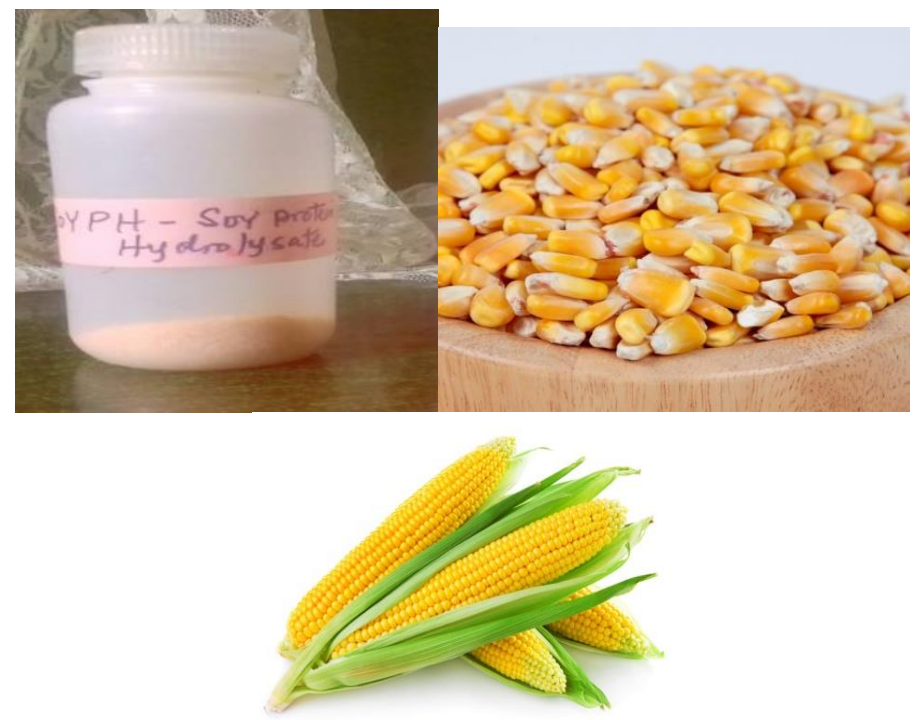

Plate 1a

\section{Raw-Material Preparations}

\section{Production of Acha Flour}

Acha flour was prepared according to the procedure in Figure 1. Cream coloured acha was sorted and washed with tap water to separate stone and sand. The washed grains $(2 \mathrm{~kg})$ were steeped in tap water $(5 \mathrm{~L})$ for a period of $72 \mathrm{~h}$ at $28 \pm$ $2{ }^{\circ} \mathrm{C}$ in a covered plastic bucket. The steep water was decanted, and the fermented grains were washed and later wet milled. The resulting paste was sieved using muslin cloth $(630 \mu \mathrm{m}$ mesh size $)$. The filtrate was allowed to settle and ferment for $72 \mathrm{~h}$ to heighten partial solidification of the acha paste. The paste was decanted and dried in an oven at $60{ }^{\circ} \mathrm{C}$ for $24 \mathrm{~h}$ to obtain the powdery form of the ogi. The cooled dried samples were dry milled, packaged in thick polythene bags and labelled appropriately (Ajanaku $\boldsymbol{e t}$ al., 2012).

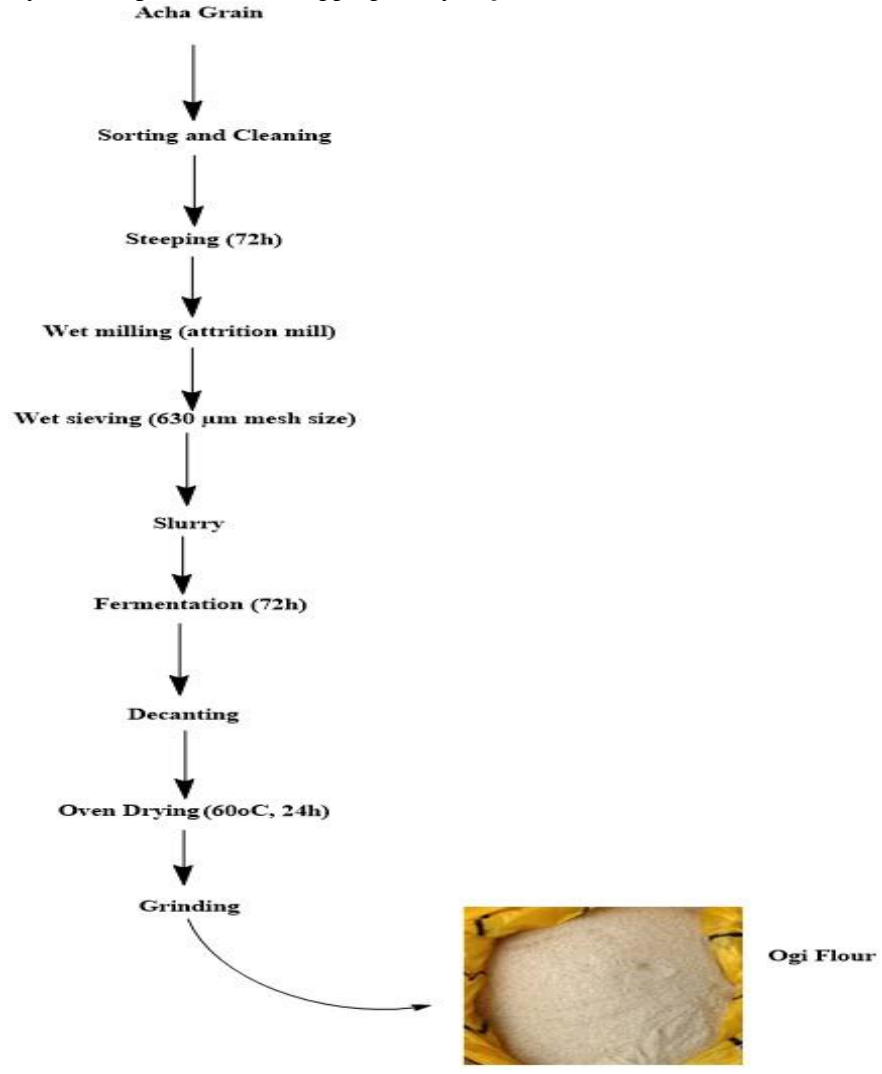

Figure 1 Flow chart for the production of fermented Acha flour (Ojo and Enujiugha, 2016).

Production of Tamba Flour

Tamba flour was prepared according to the procedure in Figure 2. Tamba seeds were sorted and washed with tap water to separate stone and sand. The washed grains $(2 \mathrm{~kg})$ were steeped in tap water $(5 \mathrm{~L})$ for a period of $72 \mathrm{~h}$ at $28 \pm 2{ }^{\circ} \mathrm{C}$ in a covered plastic bucket. The steep water was decanted, and the fermented grains were washed and later wet milled. The resulting paste was sieved using muslin cloth $(630 \mu \mathrm{m}$ mesh size). The filtrate was allowed to settle and ferment for $72 \mathrm{~h}$ to heighten partial solidification of the tamba paste. The paste was decanted and dried in an oven at $60{ }^{\circ} \mathrm{C}$ for $24 \mathrm{~h}$ to obtain the powdery form of the ogi. The cooled dried samples were dry milled, packaged in thick polythene bags and labelled appropriately (Ajanaku et al.,2012). 

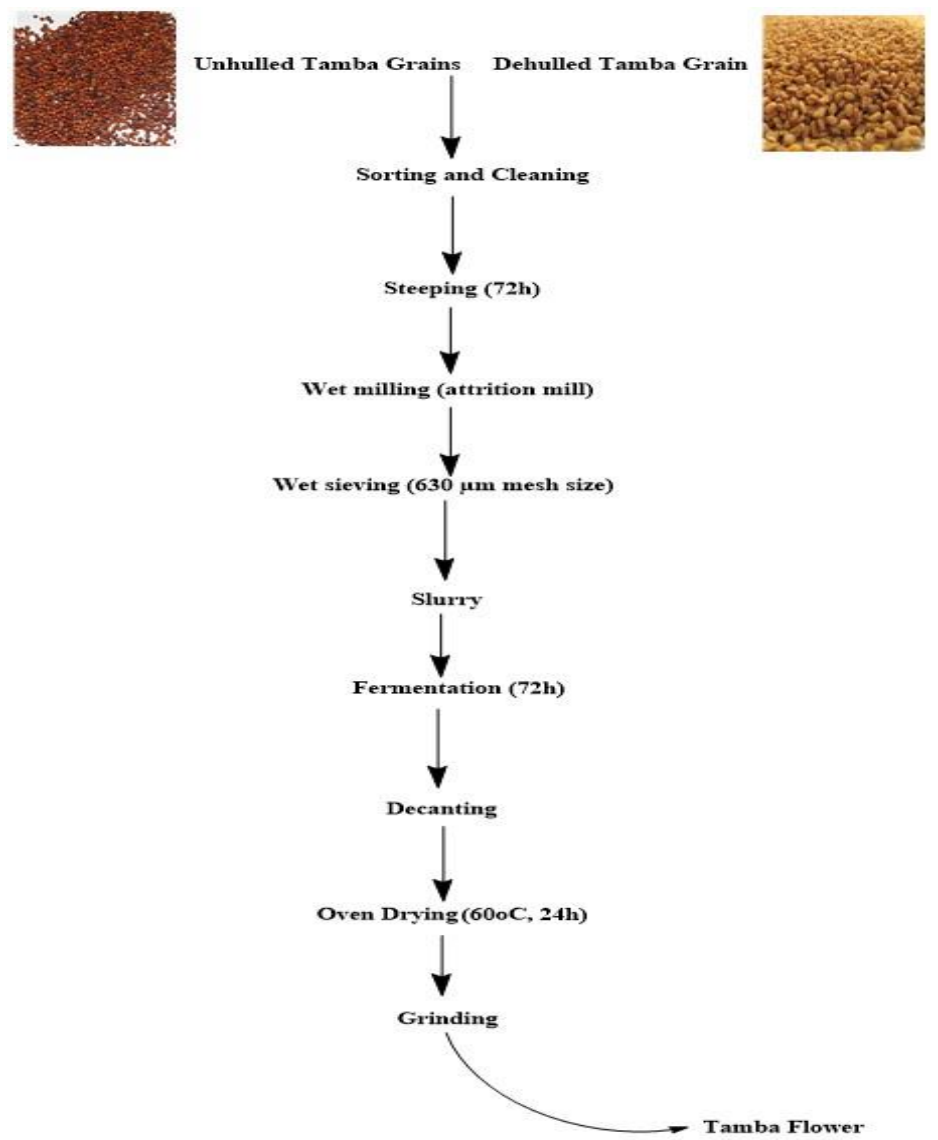

Figure 2 Flow chart for the production of fermented Tamba flour (Ojo and Enujiugha, 2016).

\section{Production of Soybean Isolate}

The principles used in the production of soy protein isolate are shown in Figure 3 . Using defatted soy flour or flakes as the starting material, the protein, alkaline $(2 \mathrm{MNaOH})$ are first dissolved in water. Acid $(2 \mathrm{MHCl})$ is then precipitated. The resulting solution is then separated from the solid residue by centrifugation method. Finally, the protein is precipitated from the solution, and then separated and dried.

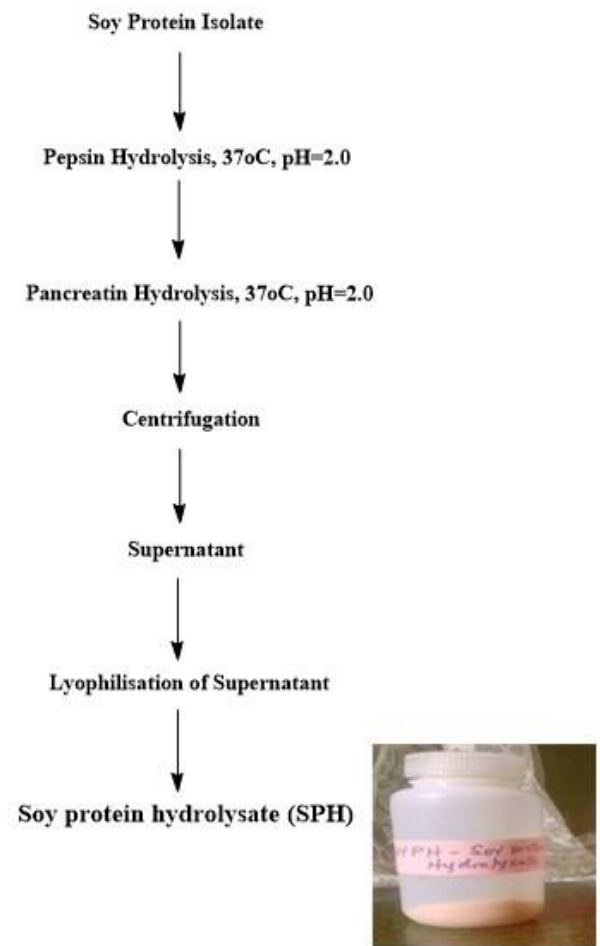

Figure 3 Production of soy protein hydrolysate from its isolates (Girgih et al., 2011).

\section{Blend Formulation}

The mix proportion for the production of acha-tamba flour enriched with soybean peptide is presented in Table 1. Figure 4 depicts the flowchart of production.

Table 1 Blend Formulation for production of acha-tamba flour enriched with soy peptides

\begin{tabular}{lllll}
\hline Blend & $\begin{array}{l}\text { Yellow com } \\
\text { (YC) }\end{array}$ & $\begin{array}{l}\text { Acha } \\
\text { flour }\end{array}$ & $\begin{array}{l}\text { Tamba } \\
\text { flour }\end{array}$ & Soy peptides \\
\hline A & 100 & 0 & 0 & 0 \\
B & 0 & 88 & 10 & 2 \\
C & 0 & 76 & 20 & 4 \\
D & 0 & 64 & 30 & 6 \\
\hline A = 100 \% yellow corn (Control), B $=88 \%$ acha $+10 \%$ tamba $+2 \%$ soy \\
peptides, C = 76\% acha $+20 \%$ tamba $+4 \%$ soy peptides, D = 64 \% acha + 30 \\
$\%$ tamba + 6 \% soy peptides, LSD = Least significant difference.
\end{tabular}

Soy peptide + Acha flour + Tamba flour (Mix)

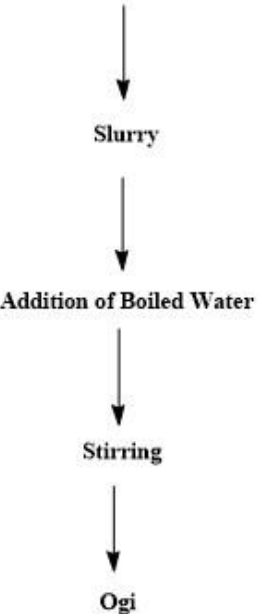

Figure 4 Flow chart for the production of acha-tamba based ogi enriched with soy peptides (Opara et al., 2012).

\section{METHOD}

\section{Proximate Analysis}

The association of official analytical chemist (AOAC, 1990) procedure was used to determine the proximate composition of Acha-Tamba Ogi and Ogi enriched with soybean peptide. Tests carried out here are described below:

\section{Determination of Crude Protein}

Crude protein was determined by Kjeldahl method using Kjeltec TM model 2300, as described in Foss Analytical manual, AB, (2003). The method involved digestion of the sample at $420^{\circ} \mathrm{C}$ for $1 \mathrm{~h}$ to liberate the organically bound nitrogen in the form of ammonium sulphate. The ammonia in the digest ammonium sulphate was then distilled off into a boric and receiver solution and then titrated with standard hydrochloric acid. A conversion factor of 6.25 was used to convert from total nitrogen to percentage crude protein (AOAC, 2005).

\section{Determination of Crude Fat Content}

Crude fat was determined by the method of AOAC (2005). This was determined using a Soxtec System HT2 fat extractor. Crude fat was extracted from the sample with hexane and the solvent evaporated off to get the fat. The difference between the initial and final weight of the extraction cup was recorded as the crude fat content.

\section{Determination of Crude Fibre Content}

Five grams $(5 \mathrm{~g})$ of each of the samples that were deflated (during fat analysis) were used in this determination. The defatted samples were each boiled in a $500 \mathrm{ml}$ flask containing $200 \mathrm{ml}$ of $1.25 \% \mathrm{H} 2 \mathrm{SO} 4$ solution under reflux for 30munites. When this time elapsed, the samples were washed with several portion of hot boiling water using a twofold muslin cloth to trap the residual particles. The residual particles in each case were carefully transferred qualitatively back to the flasks and $200 \mathrm{ml}$ of $1.25 \% \mathrm{NAOH}$ solution was then added into each flask. Again, the samples were boiled for 30 minutes and washed as before with hot water. Then they were each carefully transferred into a 
weighed crucible and then dried in a Genlab oven set at $105 \mathrm{oc}$ for 3 hours. The dried samples were then transferred into desiccators where they cooled for about 20 minutes before being weighed again. After weighing they were transferred into a muffle furnace set at $550 \mathrm{oc}$ for 2 hours (until them ashed). Finally, they were cooled in desiccators and weighed again. The crude fiber content for each sample was calculated thus.

\section{Percentage Moisture Content $=(\mathrm{W} 2-\mathrm{W} 3) /(\mathrm{W} 1) \mathrm{X} 100 / 1$}

Where W2= weight of crucible + sample after washing and drying in the oven $\mathrm{W} 3=$ weight of crucible + sample as ash and $\mathrm{W} 1=$ weight of the original sample.

\section{Determination of Moisture Content}

Five grams of sample was weighed into a Petri-dish of known weight. The weighed sample was put into an oven pre-set at $110^{\circ} \mathrm{C}$ for $3 \mathrm{~h}$. The sample was removed and cooled in a dessicator to room temperature and the weight was determined after which it was returned into the oven at $110^{\circ} \mathrm{C}$ for 30 min until constant weight was obtained: AOAC (2005).

\section{Determination of Ash Content}

Five grams of sample was weighed into a previously ignited and cooled silica dish. The dish was ignited gently first and then at $600^{\circ} \mathrm{C}$ for $3 \mathrm{~h}$ in a muffle furnace. The dish and its content were cooled in a dessicator and reweighed; the weight of the residue was recorded as ash content.

\section{Determination of Carbohydrate Content}

The carbohydrate content was estimated by subtracting the sum of percentage of moisture, fat, protein and ash contents from 100\% according to AOAC (1995).

\section{Functional Properties of Ogi}

\section{Determination of Bulk Density (BD)}

Bulk Density was determined using the method described by Wang and Kinsella (1976) with slight modifications. $10 \mathrm{~g}$ of the test materials were placed in a 25 $\mathrm{mL}$ graduated cylinder and packed by gentle tapping the cylinder on the bench top ten times from a height of $5-8 \mathrm{~cm}$. The final volume of the test material was recorded and expressed as $\mathrm{g} / \mathrm{ml}_{-}$.

$$
\text { Bulk density }(\mathrm{g} / \mathrm{ml})=\frac{\text { weight of sample }(\mathrm{s})(\mathrm{g} / \mathrm{ml})}{\text { Volume of Sample }(\mathrm{ml})}
$$

\section{Determination of Swelling Index (SI)}

Swelling Index was determined using the method described by Takashi and Sieb (1988) with slight modifications. It involves weighing $1 \mathrm{~g}$ of the sample into 50 $\mathrm{mL}$ centrifuge tube; $10 \mathrm{~mL}$ of distilled water was added and mixed gently. The slurry was heated in a water bath at temperatures of $60,70,80$ and $90{ }^{\circ} \mathrm{C}$ for 30 min. On completion of $30 \mathrm{~min}$, the tube containing the paste is centrifuged $(0502$ 1 Hospibrand, USA) at $3500 \times \mathrm{g}$ for $20 \mathrm{~min}$. The supernatant was decanted immediately after centrifuging. The weight of the sediment was recorded. The moisture content of the sediment gel was used to determine the dry matter content of the gel. The parameters were used to calculate the swelling capacity.

$$
\text { Swelling Index }=\frac{\text { Change in volume of sample }}{\text { original weight of sample }}
$$

\section{Determination of Water Absorption Capacity (WAC)}

Water absorption capacity (WAC) was determined by the method of Cegla et al. (1977) with slight modifications. $10 \mathrm{~g}$ of each formulation were weighed in a 100 $\mathrm{mL}$ beaker. A known volume $(5 \mathrm{~mL})$ of water was pipetted into the beaker carefully stirred and allowed to equilibrate for one hour at room temperature (23 $25^{\circ} \mathrm{C}$ ). After complete water absorption, the sample was further treated with 0.01 $\mathrm{mL}$ water portion at $10 \mathrm{~min}$ interval before visual observation. The volume that gave a complete absorption of water (no visible free water) was recorded. Water absorption capacity was calculated as the ratio of maximum amount of water in grams absorbed by $100 \mathrm{~g}$ dry material.

\section{Determination of Oil Absorption Capacity (OAC)}

Oil absorption capacity (OAC) of each of the samples was determined by the method illustrated by Appiah et al. (2011) with slight modifications. A sample of $1 \mathrm{~g}$ was weighed into a previously weighed centrifuge tube $(40 \mathrm{~mL}$ in volume $)$ and $10 \mathrm{~mL}$ of pure Gino ${ }^{\circledR}$ oil was added into the sample in tube. The sample was mixed with $10 \mathrm{~mL}$ of pure Gino ${ }^{\circledR}$ oil for $60 \mathrm{~s}$. The mixture was allowed to stand for $10 \mathrm{~min}$ at room temperature, centrifuged at $2000 \times \mathrm{g}$ for $30 \mathrm{~min}$ using a centrifuge (0502-1 Hospibrand, USA). The oil phase was carefully decanted and the tube was allowed to drain at a $45^{\circ}$ angle for $10 \mathrm{~min}$ and then weighed. OAC was expressed as percentage of the volume of oil absorbed by the sample.

\section{Determination of Least Gelation Concentration (LGC)}

Sample suspensions of 2 to $20 \%$ (w/v) were prepared in $5 \mathrm{~mL}$ distilled water in test tubes. The tubes containing the suspensions were then heated for $1 \mathrm{~h}$ in a boiling water bath. The tubes, after heating, were cooled rapidly in water at $4{ }^{\circ} \mathrm{C}$ for $2 \mathrm{~h}$. Each tube was then inverted. The concentration at which the sample from the inverted test tube did not slip was taken as the LGC (Sathe and Salunkhe, 1981)

\section{Determination of the Chemical Properties of Ogi}

Chemical composition of the sample such as $\mathrm{pH}$, Total titrable acidity and total soluble solid were determined using the methods of AOAC (2005). The changes in $\mathrm{pH}$ as the fermentation progressed were measured using a Metrohm $620 \mathrm{pH}$ meter (MetrohmHerissau, Switzerland) with a reference glass electrode. The $\mathrm{pH}$ meter was calibrated prior to each reading using standard buffers (from the manufacturer). The Total Titrable Acidity (TTA) was determined by titrating 20 $\mathrm{ml}$ of the fermenting sample against $0.1 \mathrm{M} \mathrm{NaOH}$ to $\mathrm{pH} 8.30$. The relative lactic acid content present was determined as percentage lactic acid on a dry matter basis.

\section{Sensory Evaluation}

The ogi powder was reconstituted and made into porridge by addition of equa amount of water to form slurry and then stirred with hot water at $100 \mathrm{oC}$ under source of heat. The ogi porridge was evaluated for taste, appearance, thickness (consistency), aroma and overall acceptability by a 20 member panellist selected from the College of Food Technology, University of Agriculture Makurdi, Nigeria; based on familiarity and interest. The parameters were rated on a 9-point hedonic scale (1-9) where 9 was liked extremely and 1, disliked extremely data for each parameter were reported as means of 20 judgments. Analysis of variance computed using SPSS 15 for each sensory attribute and the Duncan multiple range tests was used to separate the means where significant difference existed (Iwe, 2002).

\section{Statistical Analysis}

All analytical determinations were conducted in duplicates. Means and standard deviations were calculated. Data obtained was subjected to analysis of variance (ANOVA). Where significant differences existed, Tukey's test was used in separating the means described by Ihekoronye and Ngoddy (1985).

\section{RESULTS AND DISCUSSION}

Proximate composition of acha-tamba flour enriched with soy peptides functional Ogi

The proximate composition of acha-tamba flour for ogi production enriched with soy peptide is presented in Table 1 . The result showed that yellow corn only, which served as the control (sample A) had the least moisture content of (10.06 $\%$ ) when compared to the composite acha-tamba flour extended with differen levels of soy peptides. All soy peptides extended samples exhibited higher moisture content than the control which ranged from $11.3-11.5 \%$ and decreased as the level of substitution of tamba for acha increased. The high moisture content in the blendedand extended samples could be attributed to the addition of soy peptides which has been reported to have a good water absorption capacity than the individual original samples hence more exposed bonding sites. In terms of keeping quality, sample A showed a superior quality over the rest of the samples because of its low moisture content.Similarly, for the ash content, the control sample A (yellow corn) had the least values $(3.05 \%$ ) followed by sample D $(3.30 \%)$ while sample B had the highest moisture content of $(3.34 \%)$. There was an inverse relationship between the level of soy peptides substitution and the ash content. The ash content of the composite flours decreased as the levels tamba flour and soy peptides addition increased. The low ash content of the yellow corn in comparison with that found in the composite flours is attributed to the fact that yellow corn has been reported to have very little amount of minera (Suri and Tanumihardjo, 2016), compared to acha and tamba. In addition, as the percentage of soy peptides increased in the mixture, the ash content reduced significantly. In contrast, the protein result showed an increase in protein conten as the extension with tamba and soy peptides increased. The protein content in the extended composite flours ranged from 4.09 to $8.02 \%$ which was significantly $(\mathrm{p}<0.5)$ higher than the protein contained in the yellow corn (sample A), which exhibited the lowest protein value $(2.15 \%)$, The highest protein content recorded by sample $\mathrm{D}$ could be attributed to the high soy peptide inclusion in the flour mix which is rich in free amino acids. The result on the fat content as presented in Table 2 showed that yellow corn (sample A) had the highest fat content of $(5.15 \%)$ followed by sample B $(4.57 \%)$ with sample D 
recording the lowest fat content $(3.79 \%)$. This result has shown that, enriching samples with soy peptides due to its high protein content could have been responsible for the reduced fat content in the blends. The higher fat content in the control could make these composite flour products susceptible to oxidative rancidity and ultimately loss its sensory appeal to the consumer. The fiber content results showed that yellow corn (sample A) had the highest fiber content (10.56 $\%)$ followed by sample B $(9.65 \%)$ and sample D $(7.65 \%)$ ranked least in fiber content. An inverse trend in fiber content was observed as the quantity of soy peptide increased in the flour blends. Fiber is important in enhancing bowel movement and in amelioration of diabetes, atherosclerosis and hypertension (Anderson et al., 2009; Caligiuri, 2014). The carbohydrate content of flours showed that yellow corn (sample A) had the highest carbohydrate content of $(69.02 \%)$ followed by B $(66.93 \%)$ with sample D $(65.95 \%)$ exhibiting the lowest. Lowering of the carbohydrate content while improving the protein content as well as that of other essential nutrients was one the intention of this project work and in this study, the protein and ash contents were enhanced in the extended flour blends than in the control. In summary, the proximate results showed low moisture content of the flour blends which is desirable and an indication that these samples will be stable during storage. According to Adeyeye and Adejuyo (1994), the low moisture content of the samples would hinder the growth of micro-organism and increase the shelf life of the samples. Sample A had the highest fiber content. According to Norman and Joseph (1995), fiber has an important function in providing roughage or bulk that aids in digestion, softens stool and lowers plasma cholesterol level in the body.

Table 2 Proximate composition of Acha-Tamba flour enriched with soy peptides for Ogi production

\begin{tabular}{lllllll}
\hline Sample & $\begin{array}{l}\text { Moisture } \\
(\boldsymbol{\%})\end{array}$ & $\begin{array}{l}\text { Ash } \\
(\boldsymbol{\%})\end{array}$ & $\begin{array}{l}\text { Protein } \\
(\boldsymbol{\%})\end{array}$ & $\begin{array}{l}\text { Fat } \\
(\boldsymbol{\%})\end{array}$ & $\begin{array}{l}\text { Fibre } \\
(\boldsymbol{\%})\end{array}$ & $\begin{array}{l}\text { Cho } \\
(\boldsymbol{\%})\end{array}$ \\
\hline A & $10.1 \mathrm{c} \pm 0.05$ & $3.05 \mathrm{~b} \pm 0.04$ & $2.15 \mathrm{~d} \pm 0.07$ & $5.15 \mathrm{a} \pm 0.07$ & $10.6 \mathrm{a} \pm 0.07$ & $69.2 \mathrm{a} \pm 0.00$ \\
B & $11.5 \mathrm{a} \pm 0.01$ & $3.34 \mathrm{a} \pm 0.01$ & $4.09 \mathrm{c} \pm 0.01$ & $4.57 \mathrm{~b} \pm 0.01$ & $9.65 \mathrm{~b} \pm 0.13$ & $66.9 \mathrm{~b} \pm 0.12$ \\
C & $11.4 \mathrm{a} \pm 0.01$ & $3.32 \mathrm{a} \pm 0.01$ & $6.08 \mathrm{~b} \pm 0.04$ & $4.28 \mathrm{c} \pm 0.03$ & $8.65 \mathrm{c} \pm 0.07$ & $66.3 \mathrm{c} \pm 1.8$ \\
D & $11.3 \mathrm{~b} \pm 0.01$ & $3.30 \mathrm{a} \pm 002$ & $8.02 \mathrm{a} \pm 0.02$ & $3.79 \mathrm{~d} \pm 0.01$ & $7.65 \mathrm{~d} \pm 0.00$ & $65.9 \mathrm{~d} \pm 0.2$ \\
LSD & 0.08 & 0.03 & 0.12 & 0.12 & 0.23 & 0.92 \\
\hline
\end{tabular}

Values with different subscript within the same row are significantly different $(\mathrm{p} \leq 0.05)$

Key: $\mathrm{A}=100 \%$ yellow corn $(\mathrm{Control}), \mathrm{B}=88 \%$ acha $+10 \%$ tamba $+2 \%$ soy peptides, $\mathrm{C}=76 \%$ acha $+20 \%$ tamba $+4 \%$ soy peptides, $\mathrm{D}=64 \%$ acha $+30 \%$ tamba $+6 \%$ soy peptides, LSD $=$ Least significant difference.

\section{Functional properties of acha-tamba flour enriched with soy peptides}

Results for the functional properties of the samples are presented in Table 3 Results showed that, bulk density of sample B was the highest $(0.56 \mathrm{~g} / \mathrm{ml})$ which was slightly higher than that of samples C\& D $(0.55 \mathrm{~g} / \mathrm{ml})$ which were similar but higher than that of sample A with the least bulk density $(0.53) \mathrm{g} / \mathrm{ml}$. The bulk density is generally affected by the particle size and density of the sample and is very important in determining the packaging requirement, material handling and application in wet processing in food industry. It is particularly useful in the specification of products, derived from size reduction or drying processes (Karuna et al., 1996). The lower the bulk density, the higher the amount of the blend particles that can bind together leading to high energy value. In addition, higher bulk density is desirable since it helps to reduce the paste thickness which is an important factor in convalescent and child feeding. (Onimara and Egbekun, 1998). Water absorption capacity (WAC) of the samples increased with increases in substitution. Sample D had the highest WAC $(1.24 \mathrm{~g} / \mathrm{ml})$, followed by sample C $(1.22 \mathrm{~g} / \mathrm{ml})$ and sample A recorded the least value of WAC (1.01 g/ml). According to Oyerekua and Adeyeye (2004), high water absorption capacity (WAC) is desirable for the improvement of mouth feel and viscosity reduction in food products. According to Afoadek and Sefa-Dedeh (2001) increased WAC in the blends might be due to the thickness of interfacial bi-laye model of protein to protein interaction and increases with increases in the soy peptides owing to its protein content. The oil absorption capacity (OAC) of both the control and extended samples varied in a similarfashion like the WAC. The OAC increased with substitution of acha and soy peptides with the extended samples having OACs in the range of 1.46 to $1.91 \%$ which were all significantly $(p<0.05)$ higher than that of the control sample $(1.10 \%)$. High OAC is known to improve palatability and chewibility. The swelling index (SI) result clearly showed that as the quantity of soy peptides increased in the sample blends, the SI also increased. Swelling index of the sample is an indicator of the water absorption index of the granules during heating (Loos et al., 1981). The control, sample A had the least SI (3.06\%) while the extended flours had higher SI values which ranged from 3.35 to $3.50 \%$ which explains why these samples also had higher moisture content than the control. The results of the least gelation concentration (LGC) presented in Table 4.2 indicated that samples A and B had the highest and similar LGC of $(6.00 \%)$. Similarly, samples C and D had the least and similar LGC of $(4.00 \%)$. High level of least gelation capacity according to Ojo \& Enujiugha (2016) means less thickening capacity of food which is the reason why yellow corn (sample A) was associated with the highest LGC and lowest moisture content.

$\underline{\text { Table } 3 \text { Functional properties of acha-tamba flour enriched with soy peptides }}$

\begin{tabular}{llllll}
\hline Sample & Bulk Density $\mathbf{( g / m l )}$ & $\begin{array}{l}\text { WAC } \\
(\boldsymbol{\%})\end{array}$ & $\begin{array}{l}\text { OAC } \\
(\boldsymbol{\%})\end{array}$ & $\begin{array}{l}\text { SI } \\
(\mathbf{v} / \mathbf{v})\end{array}$ & $\begin{array}{l}\text { LGC } \\
(\boldsymbol{\%})\end{array}$ \\
\hline A & $0.53 \mathrm{a} \pm 0.01$ & $1.01 \mathrm{c} \pm 0.0$ & $1.10 \mathrm{~d} \pm 0.12$ & $3.06 \mathrm{a} \pm 0.06$ & $6.00 \mathrm{a} \pm 0.00$ \\
B & $0.56 \mathrm{a} \pm 0.01$ & $1.07 \mathrm{~b} \pm 0.01$ & $1.46 \mathrm{c} \pm 0.01$ & $3.35 \mathrm{a} \pm 0.01$ & $6.00 \mathrm{a} \pm 0.00$ \\
C & $0.55 \mathrm{a} \pm 0.01$ & $1.22 \mathrm{a} \pm 0.02$ & $1.66 \mathrm{~b} \pm 0.02$ & $3.40 \mathrm{a} \pm 0.07$ & $4.00 \mathrm{~b} \pm 0.00$ \\
D & $0.55 \mathrm{ab} \pm 0.01$ & $1.24 \mathrm{a} \pm 0.01$ & $1.91 \mathrm{a} \pm 0.01$ & $3.50 \mathrm{a} \pm 0.49$ & $4.00 \mathrm{~b} \pm 0.00$ \\
LSD & 0.026 & 0.026 & 0.03 & 0.69 & 0.18 \\
\hline
\end{tabular}

Values with different subscript within the same row are significantly different $(\mathrm{p} \leq 0.05)$

Key: $\mathrm{A}=100 \%$ yellow corn (Control), $\mathrm{B}=88 \%$ acha $+10 \%$ tamba $+2 \%$ soy peptides, $\mathrm{C}=76 \%$ acha $+20 \%$ tamba $+4 \%$ soy peptides, $\mathrm{D}=64 \%$ acha $+30 \%$ tamba $+6 \%$ soy peptides, $\mathrm{LSD}=$ Least significant difference

\section{Chemical properties of acha-tamba flour enriched with soy peptides}

Results for the chemical properties of the samples are presented in Table 4 Results showed that, sample B had the highest $\mathrm{pH}$ value of (4.46) followed by sample C (4.41), sample D (4.33) all of which were not significantly $(p<0.05)$ different from that of sample A with the least $\mathrm{pH}$ value of (4.27). $\mathrm{pH}$ is important parameter in determining the acid factor which is an indicator of the rate of conversion of starch to dextrin. High level of $\mathrm{pH}$ in the samples is attributed to the presence of amino acid components in the samples which determines the nutritional and functional quality of proteins which in turn plays several important roles in body physiology and development (Omole, Ighodaro \& Durosinolorun, 2017). Sample A from all indication could prevent the growth and proliferation of spoilage and pathogenic bacteria. The total titrable acid (TTA) of the samples obtained indicated thatsample D had the highest TTA value of $(0.97 \%)$ followed by sample C $(0.96 \%)$ while sample A exhibited the lowest (0.88) value. Similar trend of results for the totalsoluble solid (TSS) indicated that, sample A had the highest TSS value of $\left(9.00^{\circ}\right.$ Brix $)$ followed by sample D $\left(8.94^{\circ}\right.$ Brix), with sample B containing the lowest (8.81) TSS value. 
Table 4 Chemical Properties of acha-tamba flour enriched with soy peptides

\begin{tabular}{llll}
\hline Sample & $\begin{array}{l}\text { pH } \\
\text { (\% citric acid) }\end{array}$ & $\begin{array}{l}\text { TTA } \\
\text { (\% lactic acid) }\end{array}$ & $\begin{array}{c}\text { TSS } \\
\left({ }^{(} \text {Brix }\right)\end{array}$ \\
\hline A & $4.27 \mathrm{a} \pm 0.37$ & $0.88 \mathrm{c} \pm 0.01$ & $9.00 \mathrm{a} \pm 0.01$ \\
B & $4.46 \mathrm{a} \pm 0.01$ & $0.92 \mathrm{~b} \pm 0.02$ & $8.81 \mathrm{ab} \pm 0.01$ \\
C & $4.41 \mathrm{a} \pm 0.01$ & $0.96 \mathrm{a} \pm 0.11$ & $8.86 \mathrm{ab} \pm 0.11$ \\
D & $4.33 \mathrm{a} \pm 0.01$ & $0.97 \mathrm{a} \pm 0.01$ & $8.94 \mathrm{~b} \pm 0.01$ \\
LSD & 0.52 & 0.03 & 0.18 \\
\hline
\end{tabular}

Values with different subscript within the same row are significantly different $(\mathrm{p} \leq 0.05)$

Key: $\mathrm{A}=100 \%$ yellow corn (Control), $\mathrm{B}=88 \%$ acha $+10 \%$ tamba $+2 \%$ soy peptides, $\mathrm{C}=76 \%$ acha $+20 \%$ tamba $+4 \%$ soy peptides, $\mathrm{D}=64 \%$ acha $+30 \%$ tamba $+6 \%$ soy peptides

$\mathrm{LSD}=$ Least significant difference.

\section{Sensory evaluation of acha-tamba flour enriched with Soy peptides}

Results for the sensory evaluation of the samples are shown in Table 5. Consumers' evaluation of the samples showed that, there were significant $(\mathrm{p}<0.05)$ differences in the attributes measured between all the samples. In terms of appearance (7.70), aroma (7.05) and texture (7.50), the control was most preferred when compared to the extend samples whose ranges for these attributes were 6.30 to $6.65 ; 5.80$ to 6.63 and 6.65 to 7.20 , respectively. While there were no significant difference in appearance of the extended samples sample A had the highest mean score for appearance (7.70). Evaluation of aroma of the samples indicated showed there were no significant differences in the aroma between the extended samples and the control sample A although it had the highest mean scores for aroma of (7.05). A similar trend of results were obtained for texture of the samples as there were no significant differences among samples except that the texture of the control sample was ranked highest (7.50) and the mean scores for texture decreased with extension with tamba flour and soy peptides. The results have shown that, at the introduction of soy peptides in the blends, there was a gradual change in texture of the samples. In contrast, to the other sensory attributes measured, the taste of the extended samples B \& C (7.60 \& 7.50) were preferred to that of the control sample A (7.10) but taste generally decreased with level of extension. Finally, the mean score for the overall acceptability showed that sample A had the highest mean score of (7.55).There was no significant difference at $(\mathrm{p} \leq 0.05)$ in the overall acceptability among samples B and C with mean values 7.25 and 7.10 , respectively while sample D had the lowest mean values of 5.85 indicating that the samples with moderate inclusion of the soy peptides (B \& C) were acceptable and like almost like the control sample.

Table 5 Sensory evaluation of acha-tamba flour enriched with soy peptides

\begin{tabular}{|c|c|c|c|c|c|}
\hline Sample & Appearance & Aroma & Texture & Taste & Overall Acceptability \\
\hline A & $7.70 \mathrm{a} \pm 0.80$ & $7.05 \mathrm{a} \pm 1.39$ & $7.50 \mathrm{a} \pm 0.82$ & $7.10 \mathrm{a} \pm 1.41$ & $7.55 \mathrm{a} \pm 1.09$ \\
\hline B & $6.65 \mathrm{~b} \pm 1.46$ & $6.63 \mathrm{ab} \pm 1.73$ & $7.20 \mathrm{a} \pm 1.47$ & $7.60 \mathrm{a} \pm 1.35$ & $7.25 b \pm 1.51$ \\
\hline $\mathrm{C}$ & $6.55 \mathrm{~b} \pm 1.70$ & $6.55 \mathrm{ab} \pm 1.82$ & $7.15 \mathrm{a} \pm 1.72$ & $7.50 \mathrm{a} \pm 1.93$ & $7.10 \mathrm{~b} \pm 1.88$ \\
\hline D & $6.30 \mathrm{~b} \pm 1.56$ & $5.80 \mathrm{~b} \pm 1.57$ & $6.65 \mathrm{a} \pm 1.53$ & $5.75 b \pm 2.02$ & $5.85 \mathrm{~b} \pm 1.95$ \\
\hline LSD & 0.89 & 1.03 & 0.89 & 1.07 & 1.04 \\
\hline
\end{tabular}

Values with different subscript within the same row are significantly different $(\mathrm{p} \leq 0.05)$

Key: $\mathrm{A}=100 \%$ yellow corn (Control), $\mathrm{B}=88 \%$ acha $+10 \%$ tamba $+2 \%$ soy peptides, $\mathrm{C}=76 \%$ acha $+20 \%$ tamba $+4 \%$ soy peptides,

$\mathrm{D}=64 \%$ acha $+30 \%$ tamba $+6 \%$ soy peptides, $\mathrm{LSD}=$ Least significant difference.

\section{CONCLUSION}

The study showed that there was significant $(\mathrm{p}<0.05)$ improvement in the nutrient quality of acha-tamba ogi extended with soy peptides especially in the content of protein and ash. The functional properties (BD, WAC, SI \& OAC) of the achatamba ogi enriched with soy peptides were enhanced in comparison to the $100 \%$ yellow maize only ogi except for the LGC in which the control showed superiority. The $100 \%$ yellow maize only control exhibited the lowest $\mathrm{pH}$ value (4.27) when compared to the higher range (4.33-4.46) shown by the acha-tamba ogi samples which is good keeping attribute. Conversely, the acha-tamba ogi samples possessed higher values of both TTA and TSS than the control sample. The sensory evaluation scores indicated that sample B $(88 \%$ Acha $+10 \%$ Tamba + $2 \%$ Soy) was most acceptable for all measured attributes among the extended ogi samples, however, the $100 \%$ yellow maize only showed the best scores for these attributes.

Acknowledgments: The authors are thankful to Federal University of Agriculture Makurdi, department of food science and Technology and study participants to making this piece a reality.

Conflicts of interest: The authors declare that they have no conflicts of interest

\section{REFERENCES}

Abdullah, M.H.R.O., Ch'ng, P.E. \& Yunus, N.A. (2012). Some physica properties of musk lime (Citrus Microcarpa). International Journal of Biological, Biomolecular, Agricultural, Food and Biotechnological Engineering, 6 (12), pp. 1122-1125.

Adebowale, A.A., Adegoke, M.T., Sanni, S.A., Adegunwa, M.O. \& Fetuga, G.O. (2012). Functional properties and biscuit making potentials of sorghum-wheat flour composite. Journal of Food Technology, 7 (6) (2012), pp. 372-379. https://doi.org/10.3923/ajft.2012.372.379

Adebowale, A.A., Fetuga, G.O., Apata, C.B. \& Sannai, L.O. (2012). Effect of variety and initial moisture content on physical properties of improved millet grains. Nigerian Food Journal, 30 (1) (2012), pp. 5-10 https://doi.org/10.1016/s0189-7241(15)30007-2

Adoukonou-Sagbadja, H. (2013). Genetic characterization of traditional fonio millets (Digitaria exilis, D. iburua STAPF) landraces from West-Africa
Implications for Conservation and Breeding. Thesis. Institute of Crop Science and Plant Breeding I. Justus-Liebig University Giessen, Germany, 119. (2010) International Research Journal of Biological Sciences, Vol. 2(1), 73-79.

Adoukonou-Sagbadja, H.; Schubert, V.; Dansi, A.; Jovtchev, G.; Meister, A.; Pistrick, K.; Akpagana, K. \& Friedt, W. (2007). Flow cytometric analysis reveals different nuclear DNA contents in cultivated Fonio (Digitaria spp.) and some wild relatives from West-Africa. Plant Systematics and Evolution. 267 (1-4) 163-176. https://doi.org/10.1007/s00606-007-0552-z

Aminigo, E. R. \& Akingbala, J. O. (2004). Nutritive composition and sensory properties of ogi fortified with okra seed meal. J Appl Sci Environ Manag, 8: 23 28 https://doi.org/10.4314/jasem.v8i2.17235

Aminigo, E. R. \& Akingbala, J. O. (2004). Nutritive Composition Of Og Fortified with Okra Seed. AACC D.E. Bruns (Ed.), Official methods of analysis (10th ed), American Association of Cereal Chemists, St Paul, MN (2000).

Aminigo, E.R. \& Akingbala, J.O. (2004). Nutritive composition of Ogi fortified with Okra seed meal. J. Appl. Sci. Environ. Mgt. 8(2): 23-28.

Anderson, J. W., Baird, P., Davis, R. H., Ferreri, S., Knudtson, M., Koraym, A., \& Williams, C. L. (2009). Health benefits of dietary fiber. Nutrition reviews, 67:188-205. https://doi.org/10.4314/jasem.v8i2.17235

Ardejani, M. S. \& Orner, B. P. (2013). Obey the peptide assembly rules. Science 340 (6132): 561-562. https://doi.org/10.1126/science.1237708

Arnoldi, A., D'Agostina, A., Boschin, G., Lovati, M. R., Manzoni, C. \& Sirtori C. R. (2001). Soy protein components active in the regulation of cholesterol homeostasis. Special Publication - Royal Society of Chemistry. 269 BiologicallyActive Phytochem Food: 103-106.

Caligiuri, S. (2014). The reduction of hypertension through dietary flaxseed intervention and the identification of oxylipins as therapeutic targets in cardiovascular disease.

Chandra, S., Singh, S., \& Kumari, D. (2015). Evaluation of functional properties of composite flours and sensorial attributes of composite flour biscuits. Journal of food science and technology, 52(6), 3681-3688. https://doi.org/10.1007/s13197-014-1427-2

Elkhier, M.K.S. \& Hamid, A.O. (2008). Effect of malting on the chemical constituents, anti-nutrition factors, and ash composition of two sorghum cultivars (Feterita and Tabat). Journal of Agriculture and Biological Sciences, 4(5): 500504.

Faber, M., Jogessar, V.B. \& Benade, A. J. (2001). Nutritional status and dietary intakes of children aged 2-5 years and their care-givers in a rural South African 
community. Int J Food Sci Nutr, 52: 401-411. https://doi.org/10.1080/09637480120078285

Gibbs, B. F., Zougman, A., Masse, R. \& Mulligan, C. (2004). Production and characterization of bioactive peptides from soy hydrolysate and soy-fermented foods. Food Res Inter; https://doi.org/10.1016/j.foodres.2003.09.010

Huang, S., Frizzi, A., Florida, C. A., Kruger, D. E. \& Luethy, M. H. (2006) High lysine and high tryptophan transgenic maize resulting from the reduction of both 19- and 22-kD $\alpha$-zeins, Plant Molecular Biology, vol. 61, no. 3, pp. 525-535. https://doi.org/10.1007/s11103-006-0027-6

Korhonen, H. \& Pihlanto, A. (2003). Food-derived bioactive peptides opportunities for designing future foods. Curr Pharmaceutical Design; 9(16):1297-1308. https://doi.org/10.2174/1381612033454892

Krishna, K. R. (2013). Agroecosystems: soils, climate, crops, nutrient dynamics and productivity. Apple Academic Press. New York.

Latunde-Dada, (2000). Fermented foods and cottage industries in Nigeria. $J$. Food Sci., 20: 1-33. https://doi.org/10.1201/b16300

Li, C., Matsui, T., Matsumoto, K., Yamasaki, R. \& Kawasaki, T. (2002). Latent production of angiotensin I-converting enzyme inhibitors from buckwheat protein. J Peptide Sci; 8(6):267-274. https://doi.org/10.1002/psc.387

Lovati, M. R., Manzoni, C., Gianazza, E., Arnoldi, A., Kurowska, E., Carroll, K K. \& Sirtori, C. R. (2000). Soy protein peptides regulate cholesterol homeostasis in Hep G2 cells. $J$ Nutr; 130(10):2543-2549. https://doi.org/10.1093/jn/130.10.2543

Nagaoka, S., Futamura, Y., Miwa, K., Awano, T., Yamauchi, K., Kanamaru, Y., Tadashi, K. \& Kuwata, T. (2001). Identification of novel hypocholesterolemic peptides derived from bovine milk beta-lactoglobulin. Biochem Biophys Res Commun; 281(1):11-17. https://doi.org/10.1006/bbrc.2001.4298

Nankar, A., Grant, L., Scott, P., \& Pratt, R. C. (2016). Agronomic and kernel compositional traits of blue maize landraces from the southwestern United States. Crop Science, 56(5), 2663 2674. https://doi.org/10.2135/cropsci2015.12.0773

Nishinari, K., Fang, Y., Guo, S. \& Phillips, G. O. (2014). Soy proteins: A review on composition, aggregation and emulsification. Food Hydrocolloids 39:301-318. https://doi.org/10.1016/j.foodhyd.2014.01.013

Nwokoro, O. \& Chukwu, B.C. (2012). Studies on Akamu, a traditional fermented maize food. Revista Chilena de Nutrición, 39 (4):180-184.

Ogodo, A. C., Ugbogu, O. C., \& Ekeleme, U. G. (2015). Bacteriological quality of commercially prepared fermented Ogi (Akamu) sold in some parts of South Eastern Nigeria. World Academy of Science, Engineering and Technology, International Journal of Biological, Biomolecular, Agricultural, Food and Biotechnological Engineering, 9(6), 685-688.

Ogbonnaya, C. \& Aminat, J. A. (2008). Proximate Chemical Composition of Acha (Digitaria exilis and Digitaria iburua) Grains. Journal of Food Technology, 6 (5): 214- 216 https://doi.org/10.1002/jsfa.2740560415

Okeme, S., Omale, P. I., \& Gwamis, A. A. (2017). Acha (Digitaria SPP) production and utilization in Africa: Way forward. International Journal of Agricultural and Veterinary Sciences (IJAVS), 3(2), 16-25. https://doi.org/10.18819/ijavs.2017.1563

Onyeka, U. \& Dibia, I. (2002). Malted weaning food made from maize, soybean and groundnut and cooking banana. J. Sci. Food and Agric., 82: 513 - 516 https://doi.org/10.1002/jsfa.1060

Opara, B. J., Uchechukwu, N., Omodamiro, R. M., \& Paul, N. (2012). Production and sensory evaluation of food blends from maize-plantain-soybean as infant complementary food. Journal of Stored Products and Postharvest Research 3:75-79. https://doi.org/10.5897/jsppr11.051

Sreenivasaprasad, S., Takan, J. P., Mgonja, M. A., Manyasa, E. O., Kaloki, P., Wanyera, N., Okwade, A. M., Muthumeenakshi, S., Brown, A. E. \& Lenné, J. M. (2005). Enhancing finger millet production and utilisation in East Africa through improved blast management and stakeholder connectivity. Aspects of Applied Biology. 75: 11-22.

Suri, D. J., \& Tanumihardjo, S. A. (2016). Effects of different processing methods on the micronutrient and phytochemical contents of maize: from A to Z. Comprehensive Reviews in Food Science and Food Safety, 15: 912 926. https://doi.org/10.1111/1541-4337.12216

Tamaru, S., Suzuki, Y., Sakono, M., Fukuda, N., Ikeda, I., Konno, R., Shimizu, T., \& Suzuki, K. (2006). Dietary 5- campestenone (campest-5-en-3-one) enhances fatty acid oxidation in perfused rat liver. J. Nutr. Sci. Vitaminol. , 52, 127-133. https://doi.org/10.3177/jnsv.52.127 